Another matter satisfactorily settled was the copper standard, which had long been discussed between the four National Physical Laboratories of England, France, Germany, and America, and the ultimate figures were agreed to, so that the tables of copper conductors based on this standard will be common to all the countries.

Mr. Maurice Leblanc, of Paris, was unanimously elected to succeed Dr. Budde, as president of the I.E.C., for a term of two years, and he will therefore preside at San Francisco.

Colonel Crompton was re-elected honorary secretary for the third time.

The Spanish delegates invited the special committees to hold their next meetings in April next in Madrid, and the Russian delegate, Prof. de Chatelain, on behalf of the Russian Committee, invited the I.E.C. to hold the plenary meeting of I9I7 in St. Petersburg.

\section{BUDGETS OF CERTAIN UNIVERSITIES AND UNIVERSITY COLLEGES IN ENGLAND AND WALES.}

THE reports for the year I9I I-I2 from those univerties and university colleges in Great Britain which are in receipt of grant from the Board of Education have been issued in two bulky volumes (Cd. 7008 and $\mathrm{Cd}$. 7009). The first volume contains reports from the provincial universities and university colleges in England, and the second reports from the London college, including the medical schools, the Welsh colleges, and Dundee University College.

The tabular matter which precedes the separate reports from the various universities contains detailed information as to the income and expenditure of the places of higher education concerned. The following summaries have been compiled from the tables, and show at a glance the amount available for education and research in the universities and colleges receiving Treasury grants and how the income is expended.

\section{Universities and University Colleges.}

\section{(I) ENGLAND.}

\section{(a) Income}

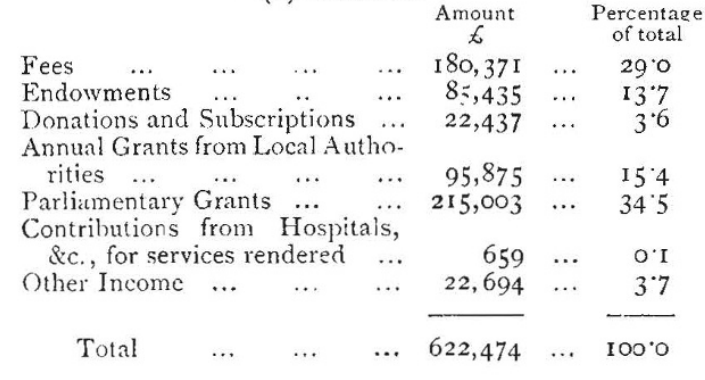

(b) Expenditure.

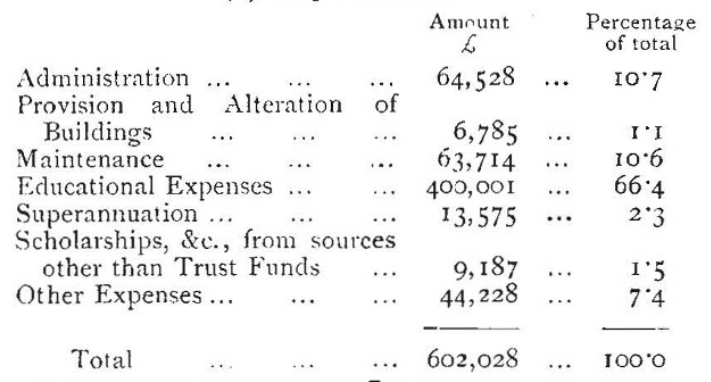

NO. 229I, VOL. 92$]$
(2) Wales.

(a) Income.

\begin{tabular}{|c|c|c|c|c|c|c|}
\hline \multirow[b]{2}{*}{ Fees $\quad \ldots$} & & $\underset{6}{\text { Amount }}$ & \multicolumn{2}{|r|}{$\begin{array}{l}\text { Percentage } \\
\text { of total }\end{array}$} \\
\hline & $\cdots$ & $\ldots$ & $\ldots$ & $18,1+7$ & $\ldots$ & $28 \cdot 2$ \\
\hline Endowments & $\ldots$ & $\ldots$ & $\ldots$ & 4, I9I & $\ldots$ & 6.5 \\
\hline Donations and & Subscri & ptior & as $\ldots$ & I,91 I & $\ldots$ & 3.0 \\
\hline Annual Gra & ts fro & $\mathrm{m}$ & Local & & & \\
\hline Authorities & & $\ldots$ & $\ldots$ & 5,283 & $\ldots$ & $8 \cdot 2$ \\
\hline Parliamentary & Grants & $\ldots$ & $\ldots$ & 33,805 & $\ldots$ & $52 \cdot 7$ \\
\hline Other Income & $\ldots$ & $\ldots$ & $\ldots$ & 890 & $\ldots$ & $1 \cdot 4$ \\
\hline Total & $\ldots$ & $\ldots$ & $\ldots$ & 64,197 & $\ldots$ & $100 \cdot 0$ \\
\hline
\end{tabular}

(b) Expenditure.

\begin{tabular}{|c|c|c|c|c|c|}
\hline Administration $\ldots$ & & & $8, \stackrel{£}{104}$ & $\ldots$ & $\begin{array}{l}\text { of total } \\
\text { I } 2 \cdot 7\end{array}$ \\
\hline Maintenance & $\ldots$ & .. & 4,659 & $\ldots$ & $7: 3$ \\
\hline Educational Expeuses & $\ldots$ & $\ldots$ & 46,399 & .. & $72 \cdot 6$ \\
\hline Superannuation $\ldots$ & $\ldots$ & & 1,640 & ... & $2 \cdot 6$ \\
\hline $\begin{array}{l}\text { Scholarships, \&c., fr } \\
\text { than Trust Funds }\end{array}$ & om & ther & & & 0.6 \\
\hline Other Expenses ... & $\cdots$ & $\cdots$ & 2,670 & $\cdots$ & $4 \cdot 2$ \\
\hline Total & $\ldots$ & $\cdots$ & 867 & $\ldots$ & 0 \\
\hline
\end{tabular}

The total income from endowments in England has increased by about $4500 l$., due chiefly to nerv endowments for Reading University College, which bring in about $4000 l$. a year, and the increased income of about I6ool. a year available for East London College. On the other hand, the income from Welsh endowments has fallen by nearly $300 l$. The total income from donations and subscriptions shows some falling-off, both in England and Wales, owing in part at least to the exclusion of donations specially earmarked for scholarship purposes. The net annual grants from local education authorities show an increase of about 10,oool. in England and about $800 l$. in Wales. The income received from Parliamentary grants increased during the year by about $58,000 l$.

The expenditure during I9II-I2 out of income upon the provision and alteration of buildings in England was more than $4000 l$. greater than in the previous year, owing in the main to heavy expenses at Leeds largely due to the provision of a hostel for women and to alterations and equipment at University College, London.

\section{THE PILTDOWN SKULL}

$\mathrm{I}$ his evening lecture to the British Association at Birmingham on September 16, Dr. Smith Woodward took the opportunity of replying to Prof. Arthur Keith's recent criticisms on his reconstruction of the Piltdown skull. It will be remembered that Dr. Woodward regarded the mandible as essentially that of an ape, and restored it with ape-like front teeth, while he determined the brain-capacity of the skull to approach closely the lowest human limit. Prof. Keith, on the other hand, modified the curves of the mandible to accommodate typically human teeth, and reconstructed the skull with a brain-capacity exceeding that of the average civilised European.

Fortunately, Mr. Charles Dawson has continued his diggings at Piltdown this summer with some success, and on August 30, Father P. Teilhard, who was working with him, picked up the canine tooth which obviously belongs to the half of the mandible originally discovered. This tooth corresponds exactly in shape with the lower canine of an ape, and its worn face shows that it worked upon the upper canine in the true ape fashion. It only differs from the canine of Dr. Woodward's published restoration in being slightly smaller, more pointed, and a little more up- 